\section{A simple protocol for tuberculin skin test reading certification}

\author{
Um protocolo simples para a certificação da \\ leitura da prova tuberculínica
}

Un protocolo simple para la certificación de la
lectura de la prueba cutánea de tuberculina
Lara de Lima Gloria 1

Mayara Lisboa Bastos 2,3

Bráulio dos Santos Júnior 4

Anete Trajman 2,5

doi: 10.1590/0102-311X00027321

\begin{abstract}
Although tuberculosis preventive therapy is one of the cornerstones for eliminating the disease, many barriers exist in the cascade of care for latent tuberculosis infection, including the need to certify healthcare professionals for reading tuberculin skin tests (TST). This paper proposes and evaluates a simple protocol for TST reading training. Primary care workers from different backgrounds received a 2-hour theoretical course, followed by a practical course on bleb reading. Blebs were obtained by injecting saline into sausages and then in volunteers. A certified trainer then evaluated the effectiveness of this protocol by analyzing the trainees' ability to read TST induration in clinical routine, blinded to each other's readings. Interobserver agreement was analyzed using the Bland-Altman test. The trainees' reading accuracy was calculated using two cut-off points - 5 and $10 \mathrm{~mm}$ - and the effect of the number of readings was analyzed using a linear mixed model. Eleven healthcare workers read 53 saline blebs and 88 TST indurations, with high agreement for TST reading (0.07mm average bias). Sensitivity was $100 \%$ (94.6; 100.0) at $5 \mathrm{~mm}$ cut-off and $87.3 \%(75.5 ; 94.7)$ at $10 \mathrm{~mm}$ cut-off. The regression model found no effect of the number of readings [coefficient: -0.007 $(-0.055 ; 0.040)]$. A simple training protocol for reading TST with saline blebs simulations in sausages and volunteers was sufficient to achieve accurate TST induration readings, with no effect observed for the number of readings. Training with saline blebs injected into voluntary individuals is safer and easier than the traditional method.
\end{abstract}

Training Courses; Observer Variation; Tuberculin Test

\author{
Correspondence \\ A. Trajman \\ Rua Macedo Sobrinho 74, apto. 203, Rio de Janeiro, RJ \\ 22271-080, Brasil. \\ atrajman@gmail.com \\ 1 Mestrado Profissional em Atenção Primária à Saúde, \\ Universidade Federal do Rio de Janeiro, Rio de Janeiro, Brasil. \\ 2 McGill University, Montréal, Canada. \\ 3 Instituto de Medicina Social, Universidade do Estado do Rio de \\ Janeiro, Rio de Janeiro, Brasil. \\ 4 Instituto Nacional de Cardiologia, Rio de Janeiro, Brasil. \\ 5 Universidade Federal do Rio de Janeiro, Rio de Janeiro, Brasil.
}




\section{Introduction}

Tuberculosis (TB) remains the first cause of death from infectious disease worldwide 1. Tuberculosis preventive therapy (TPT) is highly effective in individuals with latent tuberculosis infection (LTBI) 2 , being the cornerstone for eliminating TB by 2050 3,4. The many barriers at different steps of the cascade of care for LTBI, however, result in less than $30 \%$ of those eligible for TPT receiving a prescription and less than $19 \%$ completing treatment 5 . The effect of TPT on public health remains thus minimal 1, despite the inclusion of new shorter and safer TPT regimens by the World Health Organization (WHO) guidelines 2.

The risk of progression from LTBI to active disease is higher in those with a positive LTBI test, either the tuberculin skin test (TST) or interferon-gamma release assays (IGRA) ${ }^{6}$. Not surprisingly, TPT has been shown to be more beneficial for those with a positive LTBI test $7,8,9$. Thus, TST (or IGRA, where available) is a mandatory test in the LTBI cascade of care, except for patients living with HIV (PLHIV) or for patients younger than five years old, who have a higher risk of progressing to active disease 2. However, of the 30 million HIV-negative individuals five years of age or older that should receive TPT by 2022 4, 20 million require a positive LTBI test. TST is simple to perform, dispense with laboratory infrastructure and has good accuracy 10 . Newer and more specific TST using recombinant tuberculin based on ESAT- 6 and CP-10 proteins, have already been adopted in some BRICS countries 11,12,13.

Despite being a simple test, reproducibility of induration readings has been reported to be low $14,15,16,17$. Thus, in some health systems, certification of healthcare workers for TST reading is needed, but specific requirements for certification vary widely 15 . While ten TST applications and readings under the supervision of a certified professional are required for certification in Georgia, United States (https://dph.georgia.gov/sites/dph.georgia.gov/files/TB-TSTCertclass.pdf, accessed on 11/ Sep/2020), Brazil has established 80 to 100 readings with $80 \%$ agreement with the trainer as a requirement 18. Although protocols to train healthcare professionals for TST application and reading also vary widely, a control quality of TST performance based on a remote m-health method (mTST) has been reported as accurate, especially for readings under $5 \mathrm{~mm}$ and over $14 \mathrm{~mm}{ }^{19}$. Based on this experience 19 , we posited that a training protocol based on saline blebs simulation would be sufficient to certify healthcare professionals and tested this hypothesis.

\section{Methods}

From October 2019 to Jnauary 2020, we conducted an operational study in a primary care health unit in a high TB incidence favela in Rio de Janeiro, Brazil, setting chosen as to reduce the risk of multiple patients without any induration jeopardizing the evaluation step. Any healthcare professional or healthcare student was eligible to voluntarily participate in the training. We included all individuals who were available and agreed to participate by signing the informed consent form, and excluded those who had been previously trained. Based on reading variance reported in protocols from the 1960's 15, we established a sample of 40 trainees.

Trainees attended a 2-hour seminar on the importance of TPT and recommendations on how to identify contacts, apply, read, and interpret TST (adapted from Dick Menzies \& Linette McElroy; Supplementary Material, http://cadernos.ensp.fiocruz.br/static//arquivo/suppl1-e00027321_5854. pdf), and watched a 7-minute demonstration video from the Brazilian Ministry of Health (available at https://www.youtube.com/watch?v=fRbg7vsa44o\&t=4s). Following this theoretical introduction, the trainees participated in a reading training, where temporary blebs were produced by injecting $0.1 \mathrm{~mL}$ of saline in sausages (simulating the intradermal technique; Supplementary Figure S1, http://cadernos.ensp.fiocruz.br/static//arquivo/suppl2-e00027321_9122.pdf). Finally, to simulate the Mantoux technique, we intradermally injected $0.1 \mathrm{~mL}$ of saline in voluntary healthcare worker trainees, who signed a separate informed consent form. All blebs should have a minimum $6 \mathrm{~mm}$ diameter and last 10 to 15 minutes, like the tuberculin bleb ${ }^{20}$. Readings of both the sausages and the arm blebs were individual, each student blinded to the other readings. All training steps were provided by an experienced LTBI physician (A.T.) with no TST certification or experience with TST reading, who 
underwent training with sausages and voluntary saline blebs in the previous year as preparation for two research projects 19,21. The practical course lasted less than two hours, depending on the number of trainees attending. A schematic of the training process can be found in the Supplementary Figure S2 (http://cadernos.ensp.fiocruz.br/static//arquivo/suppl2-e00027321_9122.pdf).

To evaluate the effectiveness of this training, trainees underwent an evaluation step by reading TST indurations in service, which were compared to the reference standard of "true" induration readings by a trainer certified by the Brazilian Ministry of Health (90\% concordance in $80-100$ readings with a certified trainer). Both trainees and trainer were blinded to each other's readings, and all readings (saline simulation and tuberculin induration) were performed using a caliper ruler (Supplementary Figure S3, http://cadernos.ensp.fiocruz.br/static//arquivo/suppl2-e00027321_9122.pdf).

Interobserver agreement was set at a difference up to $2 \mathrm{~mm}$ between readings and analyzed using the Bland-Altman test 22 . The trainee's reading sensitivity and specificity and their $95 \%$ confidence intervals were calculated using $5 \mathrm{~mm}$ and $10 \mathrm{~mm}$ as cut-off points (measures used in Brazil, depending on the risk of progression to active TB and time since BCG vaccination) 23 . To verify if the number of readings or the type of product injected (saline vs. tuberculin) had any significant effect on the agreement, we developed a linear mixed model with two hierarchical levels (per patient and per reader), including all readings (blebs and indurations), having as dependent variable the absolute difference between the trainees' and trainer's results in $\mathrm{mm}$ and as independent variables: the trainer's readings, the number of readings and the type of product injected (saline or tuberculin). The model was considered robust if the mean residuals were close to zero. All analyses were performed in Stata (https:// www.stata.com).

The study was approved by the Ethics Research Committee of the Anna Nery Nursing School/São Francisco de Assis Health Care Institute, Federal University of Rio de Janeiro (n. 3.256.347 on April $10,2019)$ and by the Rio de Janeiro Health Secretariat (n. 3.470 .316 on July 25, 2019). All patients and healthcare workers signed an informed consent form before participating in the study.

\section{Results}

Of the 64 eligible healthcare workers, 15 were available for training in three different sessions. Each trainee read an average of $6.8( \pm 2.2)$ blebs in sausages and $3.5( \pm 1.3)$ blebs in volunteers. Of the 15 participants, 11 were evaluated in service with an average of $14.7( \pm 5.4)$ TST readings each. These included one pharmacist, two physicians, two registered nurses, two nursing assistants, and four community health agents with nursing assistant training. Overall, they performed 141 readings -53 blebs and 88 indurations - before the project's interruption due to the SARS-CoV-2 pandemic.

The Bland-Altman test found a high agreement for the 88 induration readings performed in 20 arms, with an average bias of $0.07 \mathrm{~mm}$ and $94.3 \%$ of the plots within the $2 \mathrm{~s}$ band (Figure 1). Sensitivity of the trainees' readings was $100 \%(94.6 \% ; 100.0 \%)$ at $5 \mathrm{~mm}$ cut-off and $87.3 \%(75.5 \% ; 94.7 \%)$ at $10 \mathrm{~mm}$ cut-off, while specificities were $95.5 \%$ (77.2\%; $99.9 \%)$ and $90.9 \%$ (75.7\%; $98.1 \%)$, respectively. Supplementary Table S1 (http://cadernos.ensp.fiocruz.br/static//arquivo/suppl2-e00027321_9122. pdf) presents the interobserver agreement by range of the trainer's reading.

As for the mixed regression model coefficients (Table 1), the number of readings had no significant effect on the agreement. Its coefficient was -0.0007 , meaning that 131 readings (estimated by $1 / 0.0007$ ) would be necessary to result in a $1 \mathrm{~mm}$ difference between the trainees' and trainer's readings. Tuberculin resulted in a $0.9 \mathrm{~mm}$ (estimated by $1 / 1.065$ ) larger difference than saline. Finally, the larger the trainer's reading, the greater the difference with the trainee's (result consistent with the lower sensitivity for the $10 \mathrm{~mm}$ cut-off). Since the mean residuals of the model were close to zero, it was considered robust. 
Figure 1

Bland-Altman agreement of tuberculin skin tests reading between trainees and trainer $(\mathrm{N}=88$, using tuberculin).

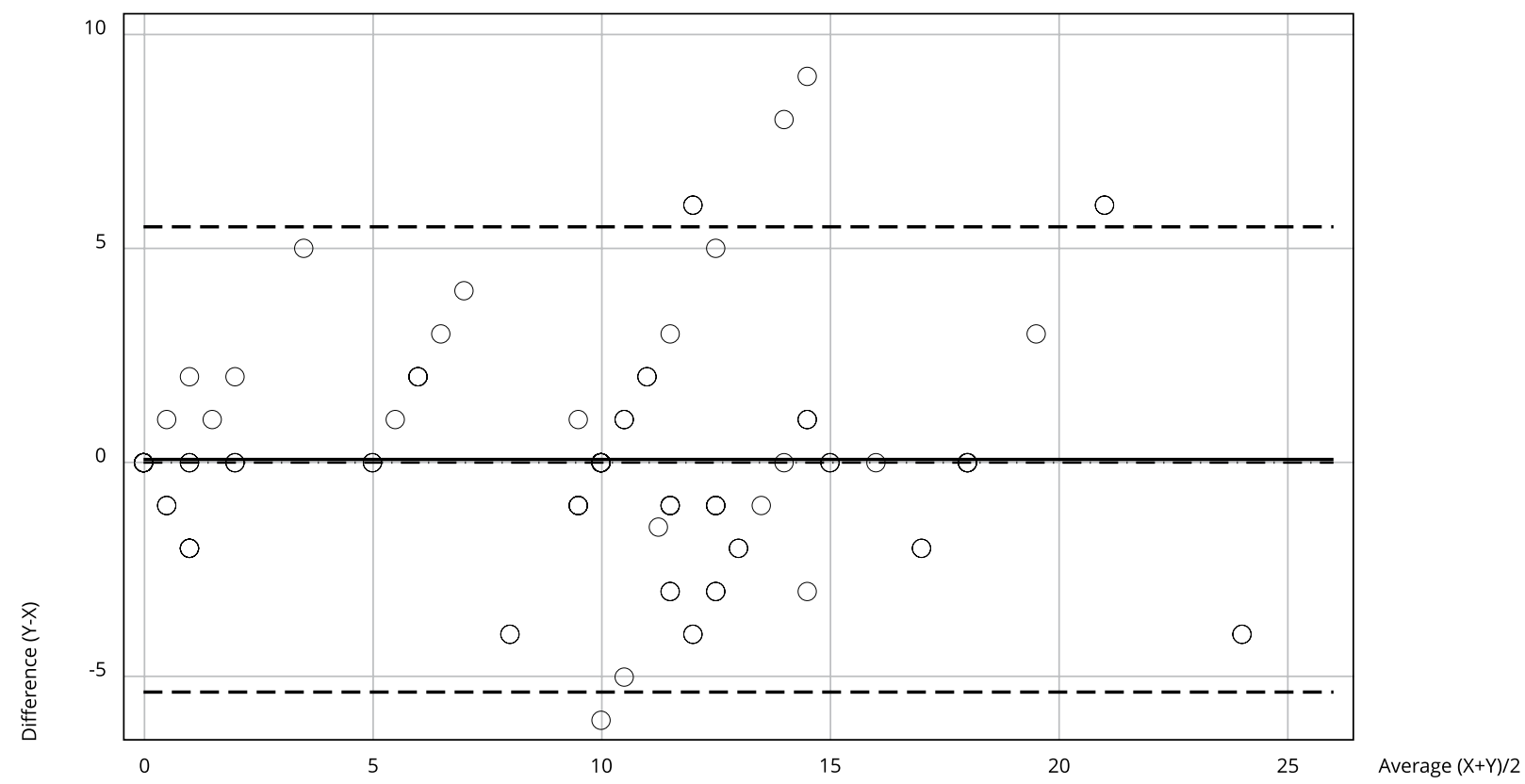

Note: the Y-axis shows the difference between trainees' and trainers' tuberculin induration readings and the X-axis, the mean value of these readings. Mean error was $0.07 \mathrm{~mm}(-0.51 ; 0.66)$. Bland \& Altman 22 recommended that $95 \%$ of the data points should be within \pm 2 s of the mean difference for measurements to be considered concordant. In this graphic, $94.3 \%$ of the points were within $\pm 2 \mathrm{~s}$.

Table 1

Independent variables associated with tuberculin skin test reading agreement between trainees and certified trainer.

\begin{tabular}{|c|c|}
\hline Independent variable * & Coefficient $(95 \% \mathrm{CI})$ \\
\hline Certified trainer reading & $0.091(0.043 ; 0.138)$ \\
\hline Type of substance applied ** & $1.065(0.309 ; 1.823)$ \\
\hline Number of readings & $-0.007(-0.055 ; 0.040)$ \\
\hline Residuals & $-5.77 e^{-16}(S D \pm 1.27)$ \\
\hline
\end{tabular}

95\% Cl: 95\% confidence interval; SD: standard deviation.

Note: $\mathrm{N}=141$ readings (53 using saline and 88 using tuberculin).

Note: bold values denote statistical significance at the $p<0.05$ level.

* Dependent variable: absolute difference in millimeters between the trainees' and the certified trainer readings;

** Tuberculin or saline (reference). 


\section{Discussion}

The simple protocol for TST reading training with saline simulations in an average of 3.5 volunteers presented here was sufficient to obtain a high agreement for TST induration readings, and a very high sensitivity for classifying patients into positive or negative results according to two different cut-off points $(5 \mathrm{~mm}$ and $10 \mathrm{~mm})$. The number of readings had no effect on the agreement. Overall, these findings suggest that training with very few saline blebs may be effective in certifying healthcare workers to read TST in service. This proposed protocol simplifies the logistics of training, is more ethically acceptable, and dispense with the need for highly experienced trainers.

Another of its advantages was training TST application, as incorrect administration of the technique was cited as a potential cause for false negative TST results 20 . An improvement to this protocol would be to add a step to evaluate the application and verify if the trainer can read the bleb size within 10 to 15 minutes, the usual duration 20 .

The literature also reports a high intra- and interobserver variability in TST reading 24,25,26, with greater differences in readings, especially when these approach positivity cut-off points 16 . Since a $2 \mathrm{~mm}$ difference, for example, represents $50 \%$ on a $4 \mathrm{~mm}$ result and only $20 \%$ on a $10 \mathrm{~mm}$ result, more errors are expected with larger readings. Larger readings could also be expected with tuberculin as the caliper ruler squeezes the bleb, which is not observed with induration. A well-conducted study comparing intra- and interobserver readings using a pair of calipers and a transparent ruler, however, showed that the variability between TST induration readings is not influenced by changing the reading instrument 27.

TST is the most widely LTBI test available and despite its limitations, the test has good accuracy, does not require laboratory facilities, and is simple to perform and interpret 19; any healthcare professional skilled in performing intradermal vaccines, as BCG, is able to inject the tuberculin. TST reading, however, has been subject to complex protocols that require a certified trainer and the availability of several voluntary arms, thus hampering its wide availability in public healthcare systems. Our findings have relevant pragmatic implications. Our protocol is also safer and more ethically acceptable. Tuberculin injection, although generally well tolerated, can cause local adverse reactions such as itching, pain, blistering, a necrotic reaction and vagal malaise ${ }^{28}$. Saline injection is safe despite mild temporary local discomfort, usually a burning sensation. An alternative method to avoid training on human arms is to use artificial arm models, but evaluating the effectiveness of such method was beyond the scope of the present study.

Our study has a few limitations. First, generalizability is difficult from the small sample of a single healthcare unit. Second, this small sample size does not allow for stratified analyses by professional background as other studies have done with the ability of paramedics 29 , pharmacists and other healthcare workers 30,31 to read TST. However, the overall performance of our participants was very good, suggesting that being able to read TST does not depend on professional background. Finally, we did not evaluate different reading techniques 32 .

Our study also has strengths, such as the in-service evaluation carried out by a certified trainer and both trainees and trainers being blinded for the readings. Also, different analyses attest to the robustness of the findings.

In summary, the simple and realistic training protocol successfully evaluated in this study may reverse the scenario of unavailability of certified personnel in LTBI cascade of care, situation created by complex certifications 33 . As new and more specific TST are developed 11,12,13, TST reading will remain a necessity. 


\section{Contributors}

L. L. Gloria contributed to the data collection and writing, and approved the final version. M. L. Bastos contributed to the study design and writing, and approved the final version. B. Santos Júnior contributed to the statistical analyses, data interpretation and writing, and approved the final version. A. Trajman contributed to the study design, data collection, analysis and interpretation and writing.

\section{Conflicts of interests}

The authors declare no conflicts of interest.

\section{Additional informations}

ORCID: Lara de Lima Gloria (0000-0002-90150656); Mayara Lisboa Bastos (0000-0003-05828870); Bráulio dos Santos Júnior (0000-0003-05828870); Anete Trajman (0000-0002-4000-4984).

\section{References}

1. World Health Organization. Global tuberculosis report 2019. http://www.who.int/tb/pu blications/global_report/en/ (accessed on 15/ $\mathrm{Jan} / 2020$ ).

2. World Health Organization. WHO consolidated guidelines on tuberculosis. Module 1: prevention. Geneva: World Health Organization; 2020.

3. Dye C, Glaziou P, Floyd K, Raviglione M. Prospects for tuberculosis elimination. Annu Rev Public Health 2013; 34:271-86.

4. United Nations. Political declaration of the UN General Assembly High-Level Meeting. https://www.who.int/tb/unhlmonTBDeclara tion.pdf (accessed on 17/Jan/2020).

5. Alsdurf H, Hill PC, Matteelli A, Getahun H, Menzies D. The cascade of care in diagnosis and treatment of latent tuberculosis infection: a systematic review and meta-analysis. Lancet Infect Dis 2016; 16:1269-78.

6. Campbell JR, Winters N, Menzies D. Absolute risk of tuberculosis among untreated populations with a positive tuberculin skin test or interferon-gamma release assay result: systematic review and meta-analysis. BMJ 2020; 368:m549.

\section{Acknowledgments}

We would like to thank the participants and healthcare managers of the clinic, Dr. Dick Menzies (McGill University, Montreal, Canada), and Linette McElroy (TB training and resource consultant, Victoria, Canada), for training two authors and providing the training material. A.T. received a grant by the Brazilian National Reseach Council (CNPq), and M.L.B. by the Canadian Institutes of Health Research (CIHR). The funding sources have no responsibility on the study conducted or the statements disclosed in this manuscript.
7. Akolo C, Adetifa I, Shepperd S, Volmink J. Treatment of latent tuberculosis infection in HIV infected persons. Cochrane Database Syst Rev 2010; (1):CD000171.

8. Smieja MJ, Marchetti CA, Cook DJ, Smaill FM. Isoniazid for preventing tuberculosis in nonHIV infected persons. Cochrane Database Syst Rev 2000; (2):CD001363.

9. Samandari T, Agizew TB, Nyirenda S, Tedla Z, Sibanda T, Shang N, et al. 6-month versus 36-month isoniazid preventive treatment for tuberculosis in adults with HIV infection in Botswana: a randomised, double-blind, placebo-controlled trial. Lancet 2011; 377:1588-98.

10. Trajman A, Steffen RE, Menzies D. Interferongamma release assays versus tuberculin skin testing for the diagnosis of latent tuberculosis infection: an overview of the evidence. Pulm Med 2013; 2013:601737.

11. Abubakar I, Jackson C, Rangaka MX. C-Tb: a latent tuberculosis skin test for the 21st century? Lancet Respir Med 2017; 5:236-7. 
12. Nikitina IY, Karpina NL, Kasimceva OV, Gergert VY, Ergeshov A, Lyadova IV. Comparative performance of QuantiFERON-TB Gold versus skin test with tuberculosis recombinant allergen (Diaskintest) among patients with suspected pulmonary tuberculosis in Russia. Int J Infect Dis 2019; 86:18-24.

13. Zellweger JP, Sotgiu G, Corradi M, Durando P. The diagnosis of latent tuberculosis infection (LTBI): currently available tests, future developments, and perspectives to eliminate tuberculosis (TB). Med Lav 2020; 111:170-83.

14. Ozuah PO, Burton W, Lerro KA, Rosenstock J, Mulvihill M. Assessing the validity of tuberculin skin test readings by trained professionals and patients. Chest 1999; 116:104-6.

15. Teruel JR, Ruffino Netto A, Duarte GG. Standardization of tuberculin test readers. Tubercle $1969 ; 50: 350-5$.

16. Goel D, Mantan M, Sethi GR. Mantoux test revisited: variability in reading tuberculin test in pediatric population. J Infect Dev Ctries 2018; 12:625-30.

17. Bearman JE, Kleinman H, Glyer VV, Lacroix OM. A study of variability in tuberculin test reading. Am Rev Respir Dis 1964; 90:913-9.

18. Departamento de Vigilância das Doenças Transmissíveis, Secretaria de Vigilância em Saúde, Ministério da Saúde. Técnicas de aplicação e leitura da prova tuberculínica. Brasília: Ministério da Saúde; 2014.

19. Moayedi-Nia S, Barss L, Oxlade O, Valiquette C, Ly M-X, Campbell JR, et al. The mTST - an mHealth approach for training and quality assurance of tuberculin skin test administration and reading. PLoS One 2019; 14:e0215240.

20. Canadian Lung Association; Canadian Thoracic Society; Public Health Agency of Canada; Centre for Communicable Diseases and Infection Control. Canadian tuberculosis standards. https://central.bac-lac.gc.ca/.item?id= HP 40-18-2014-eng\&op=pdf\&app = Library (accessed on 06/Apr/2021).

21. Oxlade O, Trajman A, Benedetti A, Adjobimey M, Cook VJ, Fisher D, et al. Enhancing the public health impact of latent tuberculosis infection diagnosis and treatment (ACT4): protocol for a cluster randomised trial. BMJ Open 2019; 9:e025831.

22. Bland JM, Altman DG. Agreement between methods of measurement with multiple observations per individual. J Biopharm Stat 2007; 17:571-82
23. Departamento de Vigilância das Doenças Transmissíveis, Secretaria de Vigilância em Saúde, Ministério da Saúde. Manual de recomendações para o controle da tuberculose no Brasil. 2a Ed. Brasília: Ministério da Saúde; 2018.

24. Kendig EL, Kirkpatrick BV, Carter WH, Hill FA, Caldwell K, Entwistle M. Underreading of the tuberculin skin test reaction. Chest 1998; 113:1175-7.

25. Pouchot J, Grasland A, Collet C, Coste J, Esdaile JM, Vinceneux P. Reliability of tuberculin skin test measurement. Ann Intern Med 1997; 126:210-4.

26. Longfield JN, Margileth AM, Golden SM, Lazoritz S, Bohan JS, Cruess DF. Interobserver and method variability in tuberculin skin testing. Pediatr Infect Dis 1984; 3:323-6.

27. Geldenhuys H, Verver S, Surtie S, Hatherill M, van Leth F, Kafaar F, et al. The tuberculin skin test: a comparison of ruler and calliper readings. Int J Tuberc Lung Dis 2010; 14:1266-71.

28. Christopher DJ, Shankar D, Datey A, Zwerling A, Pai M. Safety of the two-step tuberculin skin test in Indian health care workers. Int J Mycobacteriol 2014; 3:247-51.

29. Haynes BE, Grubb R. Paramedics can apply and read Mantoux tuberculosis tests. J Emerg Med 2001; 20:381-4.

30. Jakeman B, Gross B, Fortune D, Babb S, Tinker D, Bachyrycz A. Evaluation of a pharmacistperformed tuberculosis testing initiative in New Mexico. J Am Pharm Assoc (2003) 2015; 55:307-12.

31. Howard TP, Solomon DA. Reading the tuberculin skin test: who, when, and how? Arch Intern Med 1988; 148:2457-9.

32. Morán-Mendoza O, Tello-Zavala MC, RiveraCamarillo M, Ríos-Meza Y. Comparison of different methods and times for reading the tuberculin skin test. Int J Tuberc Lung Dis 2013; 17:1273-8.

33. Salame FM, Ferreira MD, Belo MT, Teixeira EG, Cordeiro-Santos M, Ximenes RA, et al. Knowledge about tuberculosis transmission and prevention and perceptions of health service utilization among index cases and contacts in Brazil: understanding losses in the latent tuberculosis cascade of care. PLoS One 2017; 12:e0184061. 


\section{Resumo}

A terapia preventiva da tuberculose é uma das bases para a eliminação da tuberculose. Entretanto, existem muitas barreiras na cascata de cuidados da infecção latente de tuberculose, incluindo a necessidade de certificação dos profissionais de saúde para a leitura da prova tuberculínica (PPD). Aqui, propomos e avaliamos um protocolo simples para capacitação na leitura do PPD. Profissionais na atenção primária com diferentes formações receberam um curso teórico de duas horas, seguido por um curso prático sobre a leitura da enduração. Nas sessões práticas, as pápulas foram obtidas pela injeção de solução salina em salsichas, e depois em voluntários. Depois, a eficácia do protocolo foi avaliada por um instrutor credenciado, com base na capacidade do aluno de ler a enduração do PPD na rotina clínica (em formato duplo-cego em relação às respectivas leituras). A concordância inter-observador foi analisada com o teste de Bland-Altman. A acurácia das leituras dos alunos foi calculada com dois pontos de corte: 5 e $10 \mathrm{~mm}$. $O$ efeito do número de leituras foi analisado com um modelo linear misto. Onze profissionais de saúde leram 53 pápulas de solução salina e 88 endurações de PPD. A concordância na leitura dos PPDs foi alta (média de 0,07mm de viés). A sensibilidade foi $100 \%(94,6 ; 100,0)$ com o ponto de corte de $5 \mathrm{~mm}$ e $87,3 \%(75,5 ; 94,7)$ com o ponto de corte de $10 \mathrm{~mm}$. No modelo de regressão, não houve efeito do número de leituras [coeficiente: -0,007 $(-0,055 ; 0,040)]$. Um protocolo simples de treinamento em leitura da prova tuberculinica com simulações usando pápulas criadas com solução salina em salsichas e em voluntários foi suficiente para alcançar leituras acuradas da enduração da prova, sem efeito observado pelo número de leituras. O treinamento com pápulas criadas com solução salina em voluntários é mais seguro e mais fácil, comparado com o treinamento tradicional.

Cursos de Capacitação; Variações Dependentes do Observador; Teste Tuberculínico

\section{Resumen}

La terapia preventiva de la tuberculosis es una de las piedras angulares para la erradicación de la tuberculosis. No obstante, existen muchas barreras en la cascada de cuidado de una infección latente de tuberculosis, incluyendo la necesidad de certificación, en el caso de los profesionales de atención en salud, para la lectura de la prueba cutánea de tuberculina (TST). Aquí proponemos y evaluamos un protocolo simple para el entrenamiento en la lectura de TST. Trabajadores de salud de atención primaria de diferentes contextos recibieron un curso de 2 horas teórico, seguido de una práctica en la lectura de la ampolla. Las ampollas se obtienen inyectado una solución salina en salchichas y luego en voluntarios. Posteriormente, la eficacia de este protocolo fue evaluada mediante un formador certificado a través de la habilidad del personal en formación para la lectura de induración del TST en la rutina clinica, con lecturas cegadas entre ellos. Se analizó la concordancia entre los observadores usando el test Bland-Altman. La precisión de la lectura por parte del personal en formación se calculó usando dos puntos de corte: 5 y $10 \mathrm{~mm}$. El efecto del número de lecturas fue analizado usando un modelo lineal mixto. Once trabajadores de salud leyeron 53 soluciones salinas en ampollas y 88 induraciones TST. La concordancia en la lectura del TST fue alta $(0,07 \mathrm{~mm}$ promedio de sesgo). La sensibilidad fue de un 100\% $(94,6 ; 100,0)$ usando los $5 \mathrm{~mm}$ de corte y $87,3 \%(75,5 ; 94,7)$ usando los $10 \mathrm{~mm}$ de corte. En el modelo de regresión, no hubo efecto del número de lecturas [coeficiente: -0,007 $(-0,055 ; 0,040)]$. Un simple protocolo de entrenamiento para la lectura TST con simulaciones, usando solución salina en ampollas en salchichas $y$ voluntarios fue suficiente para alcanzar lecturas precisas de induración TST, sin efectos observados por el número de lecturas. El entrenamiento con ampollas salinas en personas voluntarias es más seguro y más fácil que el entrenamiento tradicional.

Cursos de Capacitación; Variaciones Dependientes del Observador; Prueba de Tuberculina
Submitted on $04 / \mathrm{Feb} / 2021$

Final version resubmitted on 08/Apr/2021

Approved on 15/Apr/2021 